\title{
Strategi Public Relations Bali Hai Cruise Sebagai Penyedia Atraksi Wisata Bahari Di Desa Lembongan, Kecamatan Nusa Penida, Kabupaten Klungkung
}

Made Sera Septiani a, 1, I Gusti Agung Oka Mahagangga a, 2

1madeseraseptiani09@gmail.com, 2okamahagangga@unud.ac.id

a Program Studi Sarjana Destinasi Pariwisata, Fakultas Pariwisata, Universitas Udayana, Jl. Dr. R. Goris, Denpasar, Bali 80232 Indonesia

\begin{abstract}
Bali Hai Cruise is one of the companies engaged in marine tourism at Lembongan village, Klungkung regency. The cruise has been established for 28 years and until now still maintained its existence as one providers of the marine tourism providers in Bali. They offer exclusive day trips at Lembongan just in one day.

This research aims to provide an overview of the marine tourism attractions and find out public relations strategy of Bali Hai Cruise. This research uses qualitative data. Data is collected by observation, interview and literature study. There are several key concepst of this research, such as: strategy, public relations, public relations strategy, and marine tourism.

The result of the research shows that Bali Hai Cruise have a public relations strategy based on internal company relationship by maintaining the quality of human resources and still give attention on the right employee, although the company has not been consistent in financial management. While on external company relations, Bali Hai Cruise is focusing on maintaining the image and brand of the company, even though the company still gets protests from the public because of coastal private beach.
\end{abstract}

Keywords: marine tourism, public relations, internal relations, external relations

\section{PENDAHULUAN}

Public relations atau hubungan masyarakat merupakan bidang baru di pariwisata. Selain menciptakan citra usaha pariwisata terlihat kuat dalam keberadaannya, tugas public relations juga untuk menciptakan suasana usaha pariwisata menjadi kondusif, memiliki iklim kerja yang sehat, kuat dalam hubungan sosial serta mempunyai kinerja sumber daya manusia yang tinggi.

Pulau Bali merupakan destinasi pariwisata Indonesia yang ideal di mana telah banyak dibangun fasilitas penunjang pariwisata. Peran public relations dalam memberikan citra ke publik sangat baik yaitu dengan memberikan informasi terbaru dan terpercaya sehingga wisatawan dapat merasakan kenyamanan dan keamanan saat mereka berwisata ke Bali yang dilihat dari jumlah kunjungan wisatawan yang terus meningkat.

Kabupaten yang memiliki potensi wisata bahari yang menarik adalah Kabupaten Klungkung. Dilihat dari jumlah kunjungan wisatawan di Kawasan Nusa Penida sebanyak 265.545 orang (BPS Kab. Klungkung, 2017), daya tarik wisata bahari masih menjadi unggulan di
Kabupaten Klungkung di mana terdapat 70\% wisatawan yang berminat berkunjung di Kawasan tersebut. Di mana dalam kawasan tersebut terdapat Nusa Penida, Nusa Lembongan dan Nusa Ceningan yang menjadi basis wisata Bahari.

Tingginya minat wisatawan mengunjungi kawasan nusa penida, menjadikan banyak muncul pelaku usaha transportasi. Namun usaha transportasi tidak hanya sebatas mengantarkan sampai tujuan, banyak terdapat jasa pelayaran dengan menambahkan paket wisata bahari di dalamnya guna menarik wisatawan menggunakan mode jasa pelayaran tersebut. Salah satu kapal pesiar lokal yang beroperasi di Benoa yaitu Pelayaran Bali Hai.

Bali Hai Cruise merupakan kapal pesiar yang eksistensinya tetap terjaga hingga saat ini. Keberadaan kapal pesiar ini dibandingkan dengan kapal pesiar pesaingnya yang berada di pelabuhan Benoa juga memiliki harga yang paling mahal, namun Bali Hai Cruise tetap eksis dengan stabilnya kunjungan wisatawan. Hal ini dilihat dari kunjungan wisatawan, dimana dalam satu kali keberangkatan Bali Hai Cruise dapat menampung sebanyak 350 penumpang sehingga 
maksimal kunjungan wisatawan dalam satu bulan yaitu 10.500 penumpang. Selanjutnya jika dilihat pada bulan Januari 2017 kunjungan wisatawan sebanyak 9.767 penumpang atau sebesar 93\% dari kuota maksimal penumpang per-bulan, bulan Februari 2017 sebanyak 6.501 penumpang dengan persentase $62 \%$ kunjungan, bulan Maret 2018 meningkat sebanyak 7.834 wisatawan atau sebesar $74 \%$ penumpang, dan pada bulan April 2017 jumlah wisatawan meningkat kembali sebesar 8.766 wisatawan atau $83 \%$ kunjungan maksimal, sehingga ratarata kunjungan wisatawan selama empat bulan terakhir yaitu $78 \%$ dari kuota maksimal kunjungan wisatawan.

Tujuan penelitian untuk mengetahui bagaimana strategi Public relations Bali Hai Cruise sebagai penyedia atraksi wisata bahari di Desa Lembongan, Kecamatan Nusa Penida, Kabupaten Klungkung sehingga tetap eksis hingga saat ini.

\section{TINJAUAN PUSTAKA}

\subsection{Tinjauan Penelitian Sebelumnya}

Tinjauan penelitian sebelumnya yang dijadikan referensi adalah jurnal "Peran dan Strategi Humas (Public Relations) Dalam Mempromosikan Produk Perusahaan" oleh Ardhoyo (2013), selanjutnya jurnal "Pengaruh Persepsi Karyawan Mengenai Perilaku Etis Dan Whistleblowing System Terhadap Pencegahan Fraud (Studi Kasus Pada Bali Hai Cruises)" oleh Gaurina, dkk (2017), dan jurnal "Strategi Public Relations Dalam Membentuk Opini Masyarakat (Studi Deskriptif Mengenai Strategi Public Relations dalam Membentuk Opini Masyarakat Terhadap PT PLN (Persero) Wilayah Sumatera Utara)" oleh Marhamah (2013) .

\subsection{Landasan Konsep dan Teori}

Landasan konsep yang digunakan dalam jurnal ini meliputi konsep strategi (Chandler dalam Rangkuti, 2005), public relations (Ishaq, 2017), strategi public relations Public Relations, terkait internal public Relations dan external public relations (Jefkins dalam Ishaq, 2017), dan wisata bahari (Akhyaruddin dalam Putra, 2014).

\section{METODE}

Jenis data yang digunakan dalam penelitian ini adalah data kualitatif (Kusumayadi dan Sugiarto, 2000) terkait deskripsi internal public relations dan eksternal public relations.

Sumber data yang digunakan dalam penelitian ini adalah primer dan sekunder (Moleong, 2005). Data primer berupa strategi public relations Bali Hai Cruise secara internal dan eksternal. Data sekunder berupa sejarah perusahaan, visi misi, jumlah kunjungan wisatawan, dan stuktur organisasi karyawan.

Teknik pengumpulan data dalam penelitian ini menggunakan teknik observasi (Kusmayadi, 2000) dengan tujuan untuk mendapatkan gambaran yang jelas mengenai situasi dan kondisi objek penelitian yaitu strategi public relations Bali Hai Cruise. Selanjutnya teknik wawancara tidak struktur (Bungin, 2007) digunakan untuk memperoleh gambaran yang jelas mengenai fokus daya tarik yang diteliti. Serta melakukan dokumentasi (Bungin, 2007) di mana alam penelitian ini melalui foto dan video aktivitas wisata bahari

Teknik analisis data dalam penelitian ini menggunakan deskriptif kualitatif (Bungin, 2007) dimana terdapat langkah-langkah yaitu melakukan pengamatan, melakukan katagorisasi, menelusuri dan menjelaskan katagorisasi, menjelaskan hubungan-hubungan katagorisasi dan menarik kesimpulan-kesimpulan umum.

\section{HASIL DAN PEMBAHASAN}

\subsection{Gambaran Umum}

Kantor pusat PT. Bali Hai Cruise terletak di Benoa tepatnya di Jl. Wahana Tirta No.1, Benoa, Denpasar Selatan, Kota Denpasar.

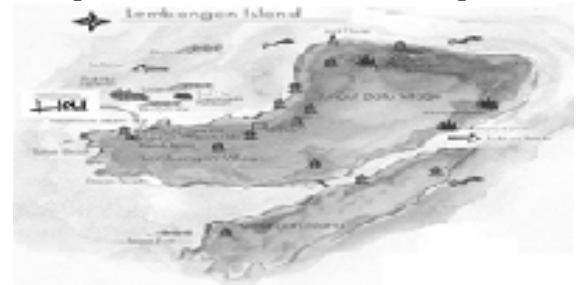

Gambar 4.1 Peta Lokasi Bali Hai Cruise Sumber: Bali Hai Diving Adventures company profile, 2016.

Berdasarkan Gambar 4.1 menunjukkan dua lokasi PT. Bali Hai Cruise yang berada di 
Kawasan Nusa Lembongan. yaitu Bali Hai Reef Cruise Pontoon lokasi ini berfungsi sebagai tempat transit Bali Hai Cruise, dan Bali Hai Beach Club and Hai Tide Beach Resort.

Bali Hai Cruises berdiri Pada Bulan Maret tahun 1990 dengan alamat Pelabuhan Benoa, Bali PO. Box. 3548 Denpasar. Perusahaan ini dimiliki oleh PT. Bali Cruises Nusantara. Bali Hai Cruises merupakan cabang dari Perusahaan yang bergerak dalam bidang yang sama yang berkedudukan di Perth Australia Barat. Bali Hai Cruise merupakan Kapal pertama di Bali pada saat itu yang digerakan oleh tenaga jet serta dilengkapi interior mewah dan serba otomatis. Tahun 1996 Bali Hai Cruises menambah satu Kapal lagi yang diberi nama (Bali Hai II). Tahun 2001 Bali Hai Cuises lagi manambah dua unit Kapal yang diberi nama Ocean Rafting I dan Ocean Rafting II. Hingga saat ini perusahaan yang bergerak di bidang wisata bahari tetap terjaga eksistensinya.

Bali Hai Cruise sendiri merancang paket wisata dalam satu hari perjalanan. Berikut adalah beberapa wisata bahari di antaranya. (1) Semi submersible coral viewer, kegiatan melihat terumbu karang dan ikan dengan kapal selam; (2) Snorkeling tour, kegiatan ini dilakukan di small pontoon; (3) Water slide, kegiatan water slide ini dilakukan di pontoon utama; (4) Banana boat rides, kegiatan ini dilakukan di Lembongan Bay; (5) Kayaking, Kegiatan ini dilakukan di dalam garis mengapung di area pantai Lembongan; (6) Parasailing; (7) Discover scuba diving; (8) Aquanauts, kegiatan ini merupakan kegiatan menyelam ke laut untuk melihat terumbu karang menggunakan tabung oksigen di kepala, dan wisatawan dapat berjalan dibawah laut. Selain wisata bahari, Bali Hai Cruise juga menyediakan beberapa atraksi maupun jasa yakni village tour di mana wisatawan akan diajak berkeliling desa lembongan, ada juga fasilitas massage, serta menyedikan akomodasi resort di pinggir pantai.

\subsection{Strategi Public relations Bali Hai Cruise Sebagai Penyedia Atraksi Wisata Bahari di Desa Lembongan}

Strategi publik relasi yang ingin diketahui yaitu berdasarkan dengan hubungan internal (dalam) perusahaan dan juga hubungan perusahaan dengan pihak eksternal (luar).

\subsubsection{Internal Relation \\ Hubungan dengan Perusahaan Rekanan}

Bali Hai Cruise yang merupakan Perusahaan di Bidang Wisata Bahari dan perhotelan tidaklah dapat bekerja sendiri tanpa adanya perusahaan rekanan. Beberapa perusahaan rekanan yang bekerja sama dengan Bali Hai Cruise adalah Photo leisure di mana perusahaan yang bekerja sama dengan Bali Hai Cruise untuk menyediakan penyambutan serta sesi foto wisatawan selama di Bali Hai Cruise, Pick-up Rent yaitu bisnis lokal yang bekerja sama dengan Bali Hai Cruise dalam menyediakan transportasi mobil saat kegiatan village tour di Desa lembongan, supplier bahan baku untuk makanan wisatawan, serta masih banyak lagi

Kerjasama antar perusahaan ini karena pihak Bali Hai Cruise membuka sebuah vendor untuk memenuhi kebutuhan perusahaan. Perusahaan rekanan yang memiliki ketertarikan dengan tawaran tersebut akan mengirimkan proposal terkait dana dan produk yang mereka tawarkan, dan akan dipilih yang memiliki kriteria sesuai dengan perusahaan. Hubungan dengan perusahaan rekanan ini memiliki berbeda-beda bentuk kerjasamanya sesuai dengan kesepakatan masing-masing.

Berdasarkan hal tersebut, maka diketahui bahwa strategi public relations Bali Hai Cruise terhadap perusahaan rekanan yaitu dengan selalu menyambut perusahan-perusahaan yang tertarik dengan tawaran perusahaan dan selalu memberikan akses kepada setiap perusahaan rekanan sesuai dengan tugas dan tanggung jawab mereka. Perusahaan akan selalu menyediakan tempat bagi perusahaan rekanan untuk melakukan aktifitas bisnis sehingga semua pihak mendapatkan keuntungan.

\section{Hubungan dengan Pemilik Saham}

Bali Hai Cruise merupakan sebuah perusahaan Persero Terbatas (PT), di mana dalam menjalankan usaha ini diperlukan modal dari saham-saham. Sehingga dalam pembangunannya Bali Hai Cruise sangat bergantung dengan pemilik saham yang secara tiba-tiba bisa datang dan pergi dari sebuah perusahaan karena saham tersebut dapat diperjual belikan. Memiliki hubungan yang baik dengan pemilik saham sangatlah penting. 
Bali Hai Cruise dalam pembangunannya juga memiliki beberapa investor yang menyuntikkan modal di dalamnya. Pemilik usaha Bali Hai Cruise juga merupakan salah satu pemegang saham dalam perusahaan. Upayaupaya yang dilakukan untuk tetap mempertahankan investor untuk tetap menaruh saham-sahamnya di Bali Hai Cruise dengan selalu mengikuti ketentuan perjanjian antara perusahaan dan pihak investor. Bali Hai Cruise melakukan upaya relasi dengan memberi informasi selengkap-lengkapnya terkait manajemen keuangan perusahaan dalam laporan keuangan yang dibuat setiap akhir tahun. Hal ini dilakukan agar para investor tetap yakin dalam memutuskan di mana akan menanamkan modal sahamnya sehingga mereka mendapatkan keuntungan. Selain itu para investor di Bali Hai Cruise selalu mendapatkan informasi mengenai resiko-resiko yang bisa terjadi di perusahaan seperti penurunan tamu dan lain sebagainya. Sistem pembagian keuntungan yang dilakukan oleh Bali Hai Cruise bersama dengan para investornya, selalu melalui kerjasama yang didasarkan oleh hukum serta disetujui oleh kedua belah pihak.

Berdasarkan hal tersebut, maka dapat diketahui bahwa strategi public relations Bali Hai Cruise dengan pemegang saham yaitu dengan tetap memberikan informasi yang jelas baik itu keuntungan maupun kerugian perusahaan serta membuat perjanjian dan disetujui oleh kedua belah pihak.

\section{Hubungan dengan Karyawan}

Karyawan merupakan bagian dari perusahaan, maka dari itu karyawan adalah sasaran utama public relations, karena jika seorang karyawan merasa nyaman dan diuntungkan dengan perusahaan maka akan semakin banyak juga keuntungan yang didapatkan sebuah perusahaan. Bali Hai Cruise yang merupakan perusahaan besar yang memiliki karyawan kurang lebih 200 karyawan, baik yang berada di kantor pusat pelabuhan Benoa maupun yang berada di Nusa Lembongan. Pemberdayaan masyarakat lokal juga dilakukan oleh pihak perusahaan dalam merekrut karyawan, di mana sebanyak 95 \% yang bekerja di Bali Hai Beach Club merupakan masyarakat Desa Lembongan yang tentunya memiliki keahlian dalam perhotelan dan wisata bahari. Fasilitas yang didapatkan setiap karyawan yaitu uang gaji pokok yang mengikuti standar Upah Minimum Kabupaten (UMK), tunjangan hari raya, Badan Penyelenggara Jaminan Sosial (BPJS) ketenagakerjaan, dan IKS di Rumah Sakit Surya Husada. Namun selain itu, karyawan juga memiliki kewajiban-kewajiban seperti dengan mengikuti aturan yang telah dibuat oleh pihak perusahaan, mengikuti perundang-undangan dalam BPJS dengan ada yang ditanggung perusahaan, ada juga yang ditanggung karyawan itu sendiri.

Hubungan perusahaan dengan karyawan dapat dilakukan sejak mereka tergabung dengan perusahaan. Bali Hai Cruise dalam merekrut karyawan baru juga melakukan pengenalan awal dengan karyawan sehingga mereka dapat paham dengan situasi dan kondisi yang ada. Terdapat program khusus yaitu Induction Program yang kegiatannya berupa orientasi untuk karyawan baru dengan mengenalkan mulai dari struktur organisasi manajemen, pengenalan produk yang perusahaan miliki, mengajak karyawan untuk melihat situasi lapangan sesuai dengan bidang karyawan baru tersebut bekerja, pelatihan Bahasa Inggris dan juga pelatihan hospitality kepada karyawan baru.

Selain menjalin hubungan dengan karyawan baru, untuk mempertahankan serta meningkatkan kualitas dari setiap karyawan yang ada baik karyawan baru maupun senior juga perlu diadakan upaya-upaya pendekatan dari perusahaan. Kegiatan tersebut bisa berupa meeting non-formal yang bertujuan untuk saling mendekatkan setiap karyawan yang ada di perusahaan. Kegiatan seperti ini sering dilakukan oleh Bali Hai Cruise, dan biasanya dilaksanakaan di hari-hari peringatan penting perusahaan, seperti ulang tahun Bali Hai Cruise. Setiap tahunnya, Bali Hai Cruise akan membuat acara peringatan hari ulang tahun di kantor pusat dengan mengundang seluruh karyawan dan keluarganya dengan disuguhkan berbagai hiburan dan doorprice.

Penghargaan maupun hukuman yang dilakukan oleh Bali Hai Cruise didasari dari program performance review yang dilakukan 6 
bulan sekali oleh setiap kepala devisi. Di mana karyawan yang akan diberikan penghargaan dinilai dari motivasi bekerjanya, loyalitas ke perusahaan, dan produktifitas dalam bekerja. Karyawan yang memiliki kulitas yang semakin baik maka akan diberikan peningkatan gaji pokoknya dan tidak menutup kemungkinan akan semakin tinggi jabatan karyawan tersebut. Selain penghargaan, hukuman juga harus diberikan kepada karyawan yang tidak bertanggung jawab agar tidak terulang kembali dan dapat merugikan perusahaan. Hukuman yang diberikan oleh Bali Hai Cruise tidak diberikan secara langsung, perusahaan telah membuat beberapa kategori pelanggaran sedang hingga pelanggaran berat. Pelanggaran yang paling sering dilakukan adalah masalah kedisiplinan datang ke kantor, lalai dalam pekerjaan, lupa tanggung jawab yang dimiliki. Berdasarkan hal ini, maka diketahui bahwa Bali Hai Cruise, sangat mempertimbangkan keputusannya dalam memberikan hukuman agar tidak membuat salah satu pihak mengalami kerugian dari keputusan tersebut.

Upaya Bali Hai Cruise dalam mengatasi masalah penurunan pemasukan bukanlah dengan penundaan pembayaran gaji, namun dengan mendorong karyawan untuk mengambil atau menghabiskan jadwal cuti dan day payment sehingga perusahaan dapat mengurangi jumlah upah pada saat penurunan jumlah kunjungan wisatawan tersebut. Kebijakan ini menjadikan kedua belah pihak baik perusahaan maupun karyawan akan mendapatkan keadilan. Sehingga akan meminimalisir tuntutan atau protes dari karyawan, yang akan berdampak pada munculnya citra negatif terhadap manajemen perusahaan. Dalam mengatasi kecelakaan kerja ini.

Berdasarkan beberapa hal tersebut maka diketahui bahwa strategi public relation Bali Hai Cruise dalam menjalin hubungan dengan karyawan yaitu dengan mengasah sumber daya manusia yang dimiliki menjadi lebih berkualitas dan selalu membuat suasana nyaman dalam bekerja dengan kegiatan keakraban sehingga memotivasi karyawan semakin prduktif, juga selalu mempertimbangankan keadilan antara karyawan dengan pihak manajemen sehingga tidak ada yang saling dirugikan satu sama lainnya.

\subsubsection{External Relation Hubungan dengan Media Massa}

Perusahaan ini sangat menyambut media massa yang akan meliput aktivitas wisata bahari Bali Hai Cruise di Nusa Lembongan. Hal ini dapat dilihat dari adanya beberapa kerjasama dengan berbagai media massa baik cetak maupun elektronik. Berikut adalah beberapa media massa yang bekerja sama dengan Bali Hai Cruise. (1) Stasiun televisi Indonesia seperti Trans7, ANTV, NET TV, SCTV, TV Surabaya dan Bali TV. Para kru akan mendapat free ticket, peliputan dilakukan hampir lima kali dalam setahun; (2) Advertising atau periklanan, Bali Hai Cruise bekerjasama di bandar udara internasional Ngurah Rai yang akan memasang iklan di ruang tunggu penumpang yang diharapkan dapat ditonton oleh tamu; (3) Website Bali Hai Cruise yaitu www.balihaicruise.com yang terdapat informasi berupa deskripsi aktivitas wisata bahari Bali Hai Cruise, harga paket wisata, jadwal paket wisata, dan bisa melakukan pemesanan tiket secara online di website tersebut; (4) Brosur dan majalah pariwisata.

Peranan media massa baik cetak maupun elektronik sangat penting, namun tidak menjadi prioritas utama, hal ini dikarenakan selain dengan media massa, Bali Hai Cruise dalam kegiatan promosi juga aktif dalam kegiata PATA (Pasific Asia Travel Asosiation) dengan melakukan treade show ke beberapa negara seperti di Berlin, Malaysia, Singapura, India dan Vietnam yang melibatkan karyawan dalam kegiatannya. Media massa yang bekerjasama untuk mempromosikan wisata bahari Bali Hai Cruise sebagian besar merupakan media-media yang ditayangkan secara internasional karena target pasar utama dari Bali Hai Cruise sendiri adalah wisatawan mancanegara.

Berdasarkan pernyataan tersebut, maka strategi public relations melalui hubungan media massa lebih kepada media massa yang ditayangkan secara internasional untuk menarik wisatawan mancanegara, walaupun tetap melakukan kerjasama dengan beberapa televisi swasta Indonesia untuk menarik kunjungan wisatawan domestik. 


\section{Hubungan dengan Pemerintah Daerah}

Bali Hai Cruise merupakan perusahaan yang letaknya berada di dua wilayah administrasi yang berbeda yaitu Kota Denpasar dan Kabupaten Klungkung, sehingga pengurusan administrasi ke pemerintahan juga dilakukan ke dua wilayah tersebut termasuk pajak yang juga dibayarkan ke dua wilayah tersebut. Dalam hubungan dengan pemerintah, Bali Hai Cruise ini sudah mendapatkan ijin pemabangunan dari dinas-dinas terkait seperti dinas perijinan dan penanaman modal, dinas lingkungan hidup dan dinas perekonomian Kabupaten Klungkung terkait penggunaan air tanah di Desa Lembongan. Dinas-dinas yang terkait juga melakukan pengecekan dan pengawasan secara berkala ke perusahaan-perusahaan yang ada termasuk di Bali Hai Cruise. Selain itu, dalam pembayaran pajak perusahaan, Bali Hai Cruise aktif dalam membayar beberapa pajak yaitu Pajak Pembangunan Satu (PB1), pajak jasa, dan pajak wisatawan yang dikenakan di Nusa Lembongan sebesar Rp. 7500 rupiah.

Selain ijin pembangunan dan pajak, Bali Hai Cruise juga sangat mendukung program pemerintah dalam kegiatan corpotare social responsibility merupakan sebuah kewajiban setiap perusahaan, bahkan diatur dalam undangundang No. 40 Tahun 2007 pasal 74 tentang Persero Terbatas (PT). Bentuk-bentuk kegiatan kepedulian lingkungan berupa program pembaharuan koral atau terumbu karang disekitar pontoon Bali Hai Cruise, hal ini sangat perlu dilakukan mengingat terumbu karang sangat penting bagi keberlanjutan wisata bahari yang sangat mengandalkan keindahan bawah lautnya. Selain itu, perusahaan juga memiliki sistem manajemen sampah dan limbah.

Berdasarkan hal tersebut, maka diketahui bahwa strategi public relatins Bali Hai Cruise terkait hubungan dengan pemerintah yaitu dengan tetap mengikuti semua aturan yang berlaku baik perijinan maupun pajak serta ikut serta dalam kegiatan pemerintah yaitu corporate social responsibility sehingga keberlanjutan sumber daya alam yang digunakan perusahaan tetap berkelanjutan.

\section{Hubungan dengan Wisatawan}

Salah satu upaya menarik wisatawan yaitu dengan tagline Bali Hai Cruise yang dimiliki yaitu "100\% Holiday In Just One Day" yang memiliki makna wisatawan akan mendapati semua pengalaman liburan dari berlayar kapal pesiar, wisata bahari, barbeque, leisure time, dan wisata budaya lokal hanya dalam satu hari, sehingga liburan wisatawan sangat bermakna dan tidak menghabiskan banyak waktu. Selain tagline, diskon juga sering diberikan oleh pihak Bali Hai Cruise kepada wisatawan. Diskon biasa diberikan untuk memperingati acara-acara besar seperti tahun baru, natal, musim libur sekolah, tahun baru cina, dan lain sebagainya.

Bali Hai Cruise juga sangat memperhatikan Standar Oprasional Prosedur (SOP) baik dalam pelayanan maupun informasi kepada wisatawan. Hal ini seperti salah satu misi perusahaan yaitu mentaati hukum dan mengadopsi penerapan prosedur yang secara international diterapkan oleh seluruh perusahaan, guna terjaganya kualitas Bali Hai Cruise sebagai penyedia atraksi wisata bahari. Perusahaan ini selalu fokus terhadap keamanan produknya sesuai prosedur internasional, Bali Hai Cruise yang selalu berlayar setiap hari kecuali hari raya nyepi ini selalu melakukan pengecekan kapal oleh teknisi kapal setiap pukul 06.00 wita untuk melihat kondisi kapal pesiar tersebut, selain itu sebelum melakukan wisata bahari wisatawan akan mendapatkan pengerahan dari lifeguard tentang keselamatan di kapal pesiar (safety demonstration). Bali Hai Cruise juga memiliki 2 paramedis yang siap membantu wisatawan ketika mengalami cedera maupun kecelakaan pada saat di kapal pesiar maupun saat melakukan aktivitas atraksi wisata bahari di Nusa Lembongan.

Keluhan atau komplain merupakan salah satu hal yang dapat memberikan citra negatif bagi sebuah perusahaan, untuk itu public relations perusahaan sangat berperan penting dalam meluruskan masalah-masalah yang muncul dalam perusahaan. Bali Hai Cruise sering mendapat keluhan atau komplin terkait cuaca yang buruk sehingga menggangu aktivitas wisata bahari. Dalam mengurangi kekecewaan wisatawan, Bali Hai Cruise selalu memasang weather advice di front office terkait informasi 
cuaca, bahkan terdapat kapal pesiar yang bila terjadi cuaca yang sangat buruk, maka kapal pesiar tersebut akan batal untuk berlayar seperti ocean rafting cruise demi keselamatan wisatawan. Selain masalah cuaca, Bali Hai Cruise juga sering mengalami komplin terkait wisatawan yang ditinggal berlayar oleh kapal pesiar, hal ini biasanya terjadi jika wisatawan sangat terlambat datang dari jadwal yang ditetapkan. Dalam hal ini, Bali Hai Cruise akan memberikan ulang tiket pada hari yang berbeda, sehingga wisatawan tersebut tetap dapat merasakan wisata bahari dari Bali Hai Cruise.

Alasan wisatawan memilih Bali Hai Cruise juga beragam baik itu karena melihat di website Bali Hai Cruise, melihat komentar-komentar tentang Bali Hai Cruise pada situs tripadvisor, saran dari agen perjalanan, maupun saran dari teman mereka yang telah terlebih dahulu menggunakan kapal pesiar ini selama berlibur di Bali, hal ini menunjukan bahwa hubungan kerjasama dengan media massa, serta adanya kepercayaan oleh Agen perjalananlokal terhadap Bali Hai Cruise juga mempengaruhi keputusan wisatawan untuk memilih Bali Hai Cruise. Para wisatawan yang telah melakukan aktivitas wisata bahari juga merasa puas dengan pelayanan yang diberikan baik dari hospitality karyawan, kapal pesiar yang bagus, makanan yang sangat bersih dan lesat.

Berdasarkan hal ini, dapat diketahui bahwa strategi public relations Bali Hai Cruise terhadap hubungan dengan wisatawan yaitu sangat menjaga kualitas pelayanan dan juga kualitas atraksi wisata bahari yang sesuai dengan SOP, sehingga citra Bali Hai Cruise di mata wisatawan tetap positif meskipun kadang terjadi masalah dengan kondisi cuaca yang tidak menentu. Keberhasilan memiliki hubungan dengan wisatawan sangat dipengaruhi juga dengan adanya kerjasama dan kepercayaan dari media massa dan agen perjalanan.

\section{Hubungan dengan Masyarakat}

Upaya Bali Hai Cruise dalam menjaga hubungan baik dengan masyarakat yakni dengan memberikan peluang kepada masyarakat yang memiliki kopetensi di bidang wisata bahari dan perhotelan untuk ikut berpartisipasi sebagai karyawan di Bali Hai Cruise sehingga selain perusahaan yang mendapatkan keuntungan, masyarakat juga dapat menikmati keuntungan dari kegiatan wisata bahari yang dimiliki Bali Hai Cruise di Desa Lembongan. Masyarakat yang menjadi karyawan pun tidak sedikit, hampir 95 $\%$ karyawan yang bekerja khusus di Bali Hai Beach Club and Hai Tide Beach Resort masyarakat dari Nusa Lembongan.

Selain dalam perekrutan, Bali Hai Cruise juga memberdayakan masyarakat yang memiliki bisnis transportasi. Semua transportasi yang digunakan untuk mengantar wisatawan mengelilingi Desa Lembongan adalah milik bisnis masyarakat, di mana dalam hal ini transportasinya adalah mobil pick up yang dibentuk sedemikian rupa sehingga bagian belakang mobil pick up berisi tempat duduk wisatawan. Bali Hai Cruise akan menyewa mobilmobil tersebut dengan tarif pembayaran sebesar Rp. $\quad 150.000$ rupiah dalam sekali jalan mengelilingi Desa Lembongan selama 45 menit. Kegitan keliling desa biasanya dilakukan tiga kali dalam satu hari, sehingga setiap mobil yang mengantar wisatawan akan dibayar Rp. 450.000 perharinya. Kegiatan village tour biasanya dengan mengunjungi pertanian rumput laut masyarakat Desa Lembongan atau kegiatan sightseeing di jembatan kuning yang merupakan penghubung Nusa Lembongan dan Nusa Ceningan.

Kegiatan sosial masyarakat merupakan salah satu bentuk hubungan perusahaan dengan masyarakat karena telah melakukan kegiatan bisnisnya di suatu wilayah sekaligus untuk mendukung program pemerintah yang mewajibkan setiap perusahaan perseroan terbatas ikut andil dalam kegiatan sosial masyarakat, Bali Hai Cruise secara rutin melakukan kegiatan sosial masyarakat yaitu sumbangan ke siswa-siswi di beberapa sekolah seperti sekolah yang berada di Nusa Ceningan, selanjutnya Bali Hai Cruise membiayai anak-anak yang kuliah pariwisata sampai tamat. Bali Hai Cruise memang lebih fokus memberikan charity atau sumbangan kepada anak-anak guna meningkatkan kualitas sumber daya manusia yang ada. Akan tetapi, walaupun Bali Hai Cruise lebih fokus kepada anak-anak sekolah, kegiatan 
sumbangan suka rela juga rutin diberikan kepada masyarakat desa jika terdapat hari raya keagamaan atapun kegiatan lain di adat Desa Lembongan. Selain sumbangan berupa material, bentuk hubungan perusahaan dengan masyarakat yaitu dalam upaya menjaga lingkungan. Bali Hai Cruise mengajak masyarakat untuk bergotong royong membersikan Desa Lembongan. Kegiatan ini biasanya dilakukan untuk memperingati hari-hari bersejarah, seperti pada peringatan hari bumi, anak-anak sekolah diajak untuk melakukan bersih-bersih pantai Lembongan.

Bali Hai Beach Club yang terletak di Desa Lembongan dibangun di sekitar pesisir pantai. Perusahaan ini juga menjadikan daerah di pesisir pantai tersebut sebagai salah satu tempat atraksi wisata baharinya, oleh karena itu pesisir pantai tersebut terisolir dari masyarakat lokal bahkan seperti pantai privat. Hal ini menyebabkan kurangnya akses yang dimiliki masyarakat menuju pantai, inilah yang sering menjadi hal yang diprotes oleh masyarakat. Masyarakat yang ingin melakukan kegiatan keagamaan atau rekreasi di area pantai susah untuk mengakses pantai tanpa adanya ijin terlebih dahulu. Di area pesisir pantai, Bali Hai Cruise menjadikan area tersebut sebagai tempat berlabuhnya kapal pesiar kecil dan beberapa aktivitas wisata bahari seperti kayaking dan banana boat. Adanya kegiatan keagamaan dikarenakan letak Bali hai Cruse yang berdekatan dengan salah satu pura di Desa Lembongan. Bali Hai Cruise pernah mendapat komplain dari masyarakat terkait aksesibilitas. Namun dalam hal ini, jika masyarakat memiliki kegiatan keagamaan atau apapun tentang kegiatan desa di pesisir pantai, maka akan diberikan ijin oleh pihak Bali Hai Cruise namun kegiatannya pun terbatas.

Jadi berdasarkan beberapa upaya-upaya yang dilakukan Bali Hai Cruise dalam menjalin hubungan dengan masyarakat, maka strategi public relation Bali Hai Cruise lebih kepada pemberdayaan masyarakat lokal untuk meningkatkan perekonomian masyarakat serta kegiatan charity atau sumbangan yang lebih berfokus kepada anak-anak sekolah guna peningkatan mutu sumber daya manusia yang dimiliki oleh masyarakat khususnya di Nusa
Lembongan. Sumbangan tersebut juga menjadi salah satu upaya untuk menjalin hubungan dengan pemerintah, di mana Bali Hai Cruise melaksanakan program wajib dari pemerintah untuk setiap perusahaan perseroan terbatas. Selain itu, dengan adanya kegiatan kepedulian sosial, juga dapat menjadi salah satu bentuk promosi kepada wisatawan karena kegiatan wisata bahari ini selain mementingkan sektor ekonomi juga peduli terhadap sosial serta lingkungan sekitar.

\section{Hubungan dengan Agen dan Guide}

Agen perjalanan dan pemandu wisata merupakan sebuah jasa yang sangat membantu dalam menentukan keputusan wisatawan dalam memilih Bali Hai Cruise sebagai tujuan wisata di Bali. Memiliki hubungan yang baik dengan agen perjalanan dan pemandu wisata sangat penting dilakukan. Terdapat beberapa agen perjalanan yang bekerja sama dengan Bali Hai Cruise seperti agen Pacto, Go Vocation Indonesia, dan Exsotic. Upaya-upaya kerjasama yang dilakukan Bali Hai Cruise dengan Agen perjalanan dan pemandu wisata yaitu dengan memberikan komisi sebanyak $10 \%$ dari harga yang terdapat di brosur ataupun di website. Jadi semua Agen perjalanan dan pemandu wisata yang membawa wisatawan ke Bali Hai Cruise akan mendapat komisi tersebut. Namun komisi akan bertambah sebesar 20\% jika Agen perjalanan dan pemandu wisata memiliki kontrak kerjasama dengan Bali Hai Cruise. Agen perjalanan dan pemandu wisata yang bekerjasama akan mendapatkan VIP card. Selain pemberian komisi, terdapat juga kebijakan free of charge terhadap pemandu wisata dengan ketentuan memiliki VIP card dan juga membawa wisatawan ke Bali Hai Cruise minimal 10 orang wisatawan.

Berdasarkan hal tersebut, maka diketahui bahwa strategi public relations Bali Hai Cruise dalam menjalin hubungan dengan agen perjalanan dan pemandu wisata yaitu selain perusahaan yang tetap menjaga kualitas serta memiliki kelebihan dalam pilihan paket wisata bahari yang beragam, perusahaan juga memberikan penghargaan berupa komisi sebagai tanda terima kasih perusahaan. Hal ini dapat memberikan citra positif dari agen perjalanan dan pemandu wisata sehingga mereka dapat terus 
membawa wisatawan untuk menggunakan jasa dan produk dari Bali Hai cruise ini.

\section{SIMPULAN DAN SARAN}

\subsection{Simpulan}

Berdasarkan hasil penelitian ini, maka diperoleh simpulan bahwa, strategi public ralations Bali Hai Cruise sebagai penyedia atraksi wisata bahari yaitu penerapan komunikasi internal dan komunikasi eksternal. Secara relasi internal, Bali hai Cruise telah mampu menyediakan informasi terkait kebijakan perusahaan, tradisi kerja, visi dan misi perusahaan terhadap pihak internal sesuai dengan komunikasi internal public relations. Secara relasi eksternal, Bali Hai Cruise mampu membentuk citra, reputasi dan opini publik secara positif terhadap pihak eksternal yang terlibat dengan komunikasi eksternal public relations.

Oleh karena itu, Bali hai Cruise merupakan perusahaan yang bergerak di bidang pariwisata bahari yang mampu dijadikan sebagai contoh penerapan ilmu public relations yang ideal

\section{DAFTAR PUSTAKA}

Ardhoyo. 2013. Peran dan Strategi Humas (Public Relations) Dalam Mempromosikan Produk Perusahaan. Jakarta: Jurnal ilmiah Widya volume 1, nomor 1.

Biro Pusat Statistik Kabupaten Buleleng. 2017. Kabupaten Klungkung Dalam Rangka Klungkung Regency in Figures 2017. Badan Pusat Statistika Kab Klungkung. Tersedia online:https://klungkungkab.bps.go.id/publication/201 7/08/11/2b5ee3764729edd6d7af4454/kabupatenklungkung-dalam-angka-2017.html.

Bungin, Burhan. 2007. "Penelitian Kualitatif". Jakarta: Kencana Media Group.

Gaurina, Purnamawati, dan Atmadja. 2017. Pengaruh Persepsi Karyawan Mengenai Prilaku Etis Dan Whistblowing System Terhadap Pencegahan Fraud (Studi Kasus Bali Hai Cruise). Singaraja: Jurnal S1 Akutansi Universitas Pendidikan Ganesha Volume 8, Nomor 2.

Human Resource office. 2016. Bali Hai Diving Adventures company profile. Denpasar: PT. Bali Cruises Nusantara.

Ishaq, Roppingi El. 2017. Public Relations Teori dan Praktek.Malang: Intrans Publishing.

Kusumayadi dan Sugiarto, Endar. 2000. Metode Penelitian dalam Bidang Kepariwisataan. Jakarta: Gramedia Pustaka Utama.

Marhamah, Annisa. 2013. Strategi Publc Relations Dalam Membentuk Opini Masyarakat (Studi Deskriptif Mengenai Strategi Public Relations Dalam Membentuk Opini karena mampu bertahan dan bersaing dengan perusahaan lain yang bergerak di bidang yang sama.

\subsection{Saran}

Berdasarkan hasil penelitian ini, maka terdapat beberapa saran yang dapat berikan yaitu:

1. Secara relasi internal, Bali hai Cruise harus konsisten dalam pemberian upah kepada karyawan, sehingga meminimalisir komplain dari karyawan. Sehingga kualitas karyawan terhadap pelayanan ke wisatawan tetap terjaga dengan baik sehingga citra positif tetap melekat di Bali Hai Cruise.

2. Secara relasi eksternal, Bali Hai Cruise harus dapat membuat kebijakan untuk memperbolehkan kegiatan keagamaan masyarakat melakukan aktivitas di pesisir pantai, karena bisa menjadi nilai tambah wisata budaya bagi wisatawan, juga agar hubungan kedua belah pihak tetap terjaga. Sehingga citra dari luar perusahaan juga dapat menjaga eksistensi perusahaan.

Masyarakat Terhdap PT PLN (Persero) Wilayah Sumatera Utara). Jurnal Universitas Sumatera Utasa (USU) Volme 2, nomor 1. Tersedia online: https://jurnal.usu.ac.id /index.php/flow/article/view/2957.

Moleong. 2005. Metodelogi Penelitian Kualitatif. Bandung: PT Remaja Rosdakarya.

Putra, I Nyoman Darma. 2014. Bali: Between Cultural and Marine Tourism. Denpasar: Jurnal Kajian Bali, Vol. 04, No.01.

Rangkuti, Freddy. 2005. Analisis SWOT: Teknik Membedah Kasus Bisnis. Jakarta: PT. Gramedia. 